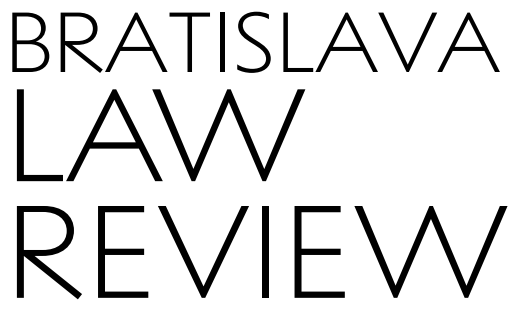

PUBLISHED BY

COMENIUS UNIVERSITY IN BRATISLAVA FACULTY OF LAW

ISSN (print): 2585-7088

ISSN (electronic): 2644-6359

\title{
FINAL THESES OF STUDENTS OF FACULTY OF LAW IN LITHUANIA: 1925-1939 / leva Deviatnikovaité
}

\author{
Prof. Dr. leva Deviatnikovaité \\ Mykolas Romeris University, \\ Faculty of Law, Institute of Public Law \\ Ateities str. 20, LT-08303 Vilnius, \\ Lithuania \\ ieva@mruni.eu \\ ORCID: 0000-0003-0982-878X
}

\begin{abstract}
The study examines the final students' theses of the Faculty of Law of the University of Lithuania (later - Vytautas Magnus University), which was the only one university during the interwar period in Lithuania. Thus, it was the only place where lawyers were prepared. The research is based on the different branches of law, considering structure, literature, legal acts, jurisprudence students used in their theses, and the Lithuanian legal language of that time. The most valuable and interesting quotes of students are presented, the teachers who assessed their works are named, and the fates of the students and teachers are revealed. The research covers over five hundred students' final theses written between 1925 and 1939. Namely such a number of final theses are held in the Department of Manuscripts of Vilnius University Library. Noteworthy that around one thousand students graduated in law during the interwar period in Lithuania. Each of this thesis was reviewed in the series of four articles published in Lithuanian language. This article summarizes all four articles and presents final conclusions. The theses reveal not only how the Faculty of Law educated lawyers, but also the legal topicalities of Lithuania at that time. Students wrote about various issues of civil, criminal, administrative, constitutional, labour, and international law. Historical, comparative, and analytical methods were used in the research.
\end{abstract}

Key words: Faculty of Law; Legal History; Legal Literature

\section{Suggested citation:}

Deviatnikovaité, I. (2021). Final Theses of Students of Faculty of Law in Lithuania: 1925-1939. Bratislava Law Review, 5(2), 101-108. https://doi.org/10.46282/blr.2021.5.2.222.
Accepted: 21 July 2021

Published: 30 December 2021

\section{INTRODUCTION}

There were only forty persons with legal education in Lithuania after the declaration of independence in 1918. Half of them did not speak or write Lithuanian. Then it is not surprising that in 1922 a modest staff of the Faculty of Law worked at the University of Lithuania. In the period from 1922 to 1932, approximately 20 to 30 positions were occupied. Meanwhile, the number of students at the Faculty was higher - in 1922 there were 244 students, and in 1932 there were 1609 students. Thus, the classes were also led by guest lecturers, and some subjects were taught not in Lithuanian, but in the German or Russian languages.

This paper represents a research in the legal history of Lithuania. The research covers over five hundred students' final theses. The object of the research is the final theses of the students of the Faculty of Law written from 1925 to 1932 . The aim of the research by evaluating the content of diploma theses is to identify legal issues in the 
interwar Lithuania and law studies. Due to the set goal, the content of the final theses, literature, legal acts, relevant case-law, legal language of students are analysed, the most valuable work citations are presented, lecturers' and students' destinies are revealed.

The article is mainly based on the documents found in the Department of Manuscripts of Vilnius University Library, the Rare Books and Manuscripts Section of the Martynas Mažvydas National Library of Lithuania, and the Central State Archives of Lithuania.

\section{UNIVERSITY OF LITHUANIA AND ITS FACULTY OF LAW}

From 1795 until 1918 one part of Lithuania was a part of the Russian empire and the other part belonged to Germany. Thus, the newly established state after the First World War had to educate new lawyers. There were serious reasons for that. In 1918 there were around forty people with legal education in Lithuania. Half of them did not write or read in the Lithuanian language. Most of them graduated from the universities of Russia. The Faculty of Law was established in 1922 in Kaunas in the University of Lithuania. The University was granted the name of Vytautas Magnus in 1930. A small number of teachers worked at the Faculty of Law. For instance, in the period of 19221932 around 20-30 people worked there. However, the number of students was growing: in 1922 there were 244 students, in 1932 there were 1609 students (Maksimaitis, 2002, p. 339). That is why some professors came to teach at the Faculty from other universities and classes were taught not only in Lithuanian, but also in the Russian and German languages (see Maksimaitis, 2002, pp. 330-335).

Final theses were assessed by a small number of teachers - legal philosopher and the Dean of Faculty professor P. Leonas, legal history professor A. Janulaitis, professor of constitutional law and the President of the University M. Romeris, administrative law professor $V$. Biržiška, professor of international law A. Jaščenka, professors of civil law V. Mačys, S. Bieliackinas, K. Šalkauskis, professors of criminal law A. Kriščiukaitis, V. Stankevičius, teacher of financial law M. Pokrovskis, associated professors A. Tamošaitis, A. Tumènas, T. Petkevičius, K. Žalkauskas, assistant A.VeryhaDarevskis and others.

\section{REQUIREMENTS FOR THE FINAL THESES}

The basic requirements for the Faculty of Law diploma were specified in the Regulation of the School of Law in 1923 (Lietuvos universiteto Teisiu fakulteto regulaminas ir mokslo planas, 1923). Under paragraph 33 of this regulation students had to pass all exams, make all tasks during the seminars, and write final theses from the fields of law or economics to get the diploma.

There were also requirements for the final theses: students should choose the topic together with the professor, the topic should be clearly formulated and related to the economical or legal life of Lithuania. Students should prove their ability to use scientific literature, methods, also ability to spread the topic properly. Technical requirements were also specified - the final thesis should be at least of twenty pages and had to be typed.

According to paragraph 54, the final theses were assessed in three ways - „very good", "good" and "satisfactory". The final thesis was assessed by two teachers, the one who helped the student with the formulation of the topic, and the other who was appointed by the dean of the Faculty. If the opinion of two teachers differed, the Dean 
appointed the third teacher. It seems that there was no defence of the final theses, but only their evaluation.

Not only the regulation was issued, which established more technical guidelines for the final theses, but also the methodological instructions were written by $\mathrm{S}$. Šalkauskis, a scientist at the Faculty of Theology and Philosophy (Šalkauskis, 1926; 1933). This work described the role of a student, his duties in the research, the maturity of a researcher, the sources, the means, the types of scientific works and the process of writing a scientific work. It is difficult to say whether students used these instructions in writing their theses - among the sources mentioned in their final theses, only one student indicated methodological instructions of S. Šalkauskis.

\section{TOPICS OF THE FINAL THESES}

Students analysed classical issues of criminal and civil law, including family law, divorce, adoption of children, inheritance law, property law, contract law, definitions of crime, offense, felony, extradition, participation of third parties in judicial proceedings, system of punishments, status of a witness, evidence, juvenile crimes, the process of cassation, civil action in criminal proceedings. They also tried to assess some current issues of that time: the principle of publicity in criminal procedure, euthanasia, criminal liability of civil servants, responsibility for the termination of pregnancy, etc.

Theses on criminal and civil law were the most popular. Over one hundred and fifty works concerning civil law were written. A lot of attention was dedicated to criminal proceedings, law enforcement, and penitentiary law - about ninety theses.

Administrative (over fifty works) and constitutional (thirty-five works) issues were also discussed in the final theses. It was popular to write about the responsibility of the Railway Board of the Republic of Lithuania, local self-government, land reform, and police. In the topics of constitutional law students compared the provisions of the constitutions of the State of Lithuania and analysed the structure, the status of legislative bodies of other states (for example, Germany, the United States, Austria, Czechoslovakia, etc.), institutes of referendum, plebiscite, status of the head of the state, etc.

Less attention was paid to the philosophy of law and legal history - over thirty works in which the ideas of capitalism and socialism were discussed.

The civil process was also not popular among students since over ten works were written on this subject. Eleven works were written on labour law and twenty on international law, including such topics as international recognition of the state, international air law, state role in international law, the League of Nations, the Permanent Court of International Justice, etc.

Moreover, students wrote about the legal aspects of the establishment of the state of Lithuania, human rights, training of future judges, the possibility of election of judges, their social guarantees, copyright, powers of notary, fingerprint identification, court of jurors, etc. Also, they assessed such questions as the organization of the bar, the monopoly of tobacco, trademarks, fair competition, legal status of foreigners, state credit, copyright, representation in the court, constitutional control of laws, railway liability, waterway administration, movies demonstration supervision, state control, business law, administrative court, press censorship, state liability.

\section{LEGAL REGULATION IN LITHUANIA IN THE INTERWAR PERIOD}

As it was noted above, one part of Lithuania was a part of the Russian Empire and another part belonged to Germany. Understandably, it was not possible to draft legal 
acts such as civil or criminal code in few months. Thus, unsurprisingly, para. 24 of the Provisional Constitution of the Lithuanian State adopted by the Council of State in 1918 established that „in areas in which the Council of State has not adopted new laws, the laws which were adopted before the war remain in force, if it does not contradict with the basic principle of the Provisional Constitution of the Lithuanian State" (Lietuvos valstybes laikinosios Konstitucijos pamatiniai desniai, 1918). In 1919 the Council of State also adopted the law on Criminal Code in which it established that the Criminal Code of Russia of 1903 remains in force in Lithuania if it does not contradict with the Provisional Constitution of Lithuania (Baudžiamasis kodeksas, 1919). Of course, during the independence period, provisions of these civil and criminal law were amended.

However, it should be noted that during the interwar period in Lithuania not only the law adopted in the Tsar Russia was in force. The laws of the German Empire and some amendments made by the Parliament of the Memel Territory and the Directory were in force in the Memel Territory. The French Civil Code (the Code of Napoleon) remained in force in Suvalkija region, which was later named as the Polish Civil Statute. In the Province of Kuršas (It. Kuršo gubernija) the code of laws of the province was in force.

Thus, during the interwar period in Lithuania four civil law systems were in force (civil laws of the Russian and German Empires, Suvalkija region and the Province of Kuršas) and two criminal law systems (of Russian and German Empires).

Noteworthy, the codes of civil, civil proceedings, criminal and criminal proceedings were not adopted during the interwar period. The students frequently mentioned this aspect in their theses and suggested to draft the new laws.

Therefore, the students had to analyse several systems of legal regulation. They analysed the jurisprudence of the Chief Tribunal of the Republic of Lithuania, the Senate of the Tsar Russian, case law of the German courts, textbooks written in the Russian and German languages and assessed the ideas of scholars from Russia and Germany.

\section{LITERATURE USED IN THE FINAL THESES}

According to the peculiarities of the legal regulation in Lithuania during the interwar period, it is not a surprise that students analysed law textbooks written mostly in the German and Russian languages.

Around 1935 the number of sources written in the Lithuanian language that students used in their works increased. While investigating criminal and civil law institutes, the Russian and German scientific literature was the most widely used.

This is also explained by the fact that once the University of Lithuania was established, all the teachers who taught there were graduates of universities in Russia. Thus, they knew the Russian language. However, the new generation of teachers, who graduated from Vytautas Magnus University, had the opportunity to study at other Western European universities. Perhaps this also explains the increase in the amount of literature used in 1935 in the English and French languages.

Noteworthy "Law" and "Lawyer" journals published shortened versions of some (apparently the most successful) graduate theses, and some of the studies were published in the separate publications of Vytautas Magnus University. This indicates that there was a lack of legal literature in the Lithuanian language and the decisions were made to publicize students' works. 


\section{THE LEGAL LANGUAGE IN THE INTERWAR LITHUANIA}

The variety of legal regulation, as well as the fact that there were no official translations of the Civil Code, the Criminal Code and procedural laws led to the problem of legal terminology. Some terms were incorrectly translated from German and Russian. Different phenomena could have been identified in the same terms.

\section{THE MOST INTERESTING QUOTES OF STUDENTS}

Students' final theses were full of thoughts that could not be found in the daily newspapers of that time, especially about the prevailing authoritarian regime in Lithuania, censorship of the press, the role of the League of Nations. This shows that the University teachers openly talked with students, discussed not only legal but also political issues.

The author of the article presumes that the authority of the President of the University Mykolas Romeris was a very important factor to maintain the spirit of freedom at the Faculty of Law. The author of the article makes this conclusion from the comments left by M. Romeris on diploma papers, some of his thoughts expressed during the classes, and quoted by the students in their final theses. Some of the quotes are presented in this paper:

"<... > we can undoubtedly say that our laws, which were created under completely different circumstances, are generally behind the laws of the civilized countries: casualty, contradictory, without any system, without exact terminology, without common concepts and legal principles" (Krasauskas, 1932, p. 38);

The League of Nations "did not deal with the political issues in Lithuania with impartiality. It made mistakes and majority of them were to the detriment of Lithuania" (Meškauskas, 1932, p. 15);

"1928 in the constitution, democracy is fable. This weakening of democracy is not so much the fact that the President of the Republic is above the Seimas, because they are both elected by the nation, but because the relationship between the President of the Republic and the nation is disadvantageous for the nation and it is a fact that cannot be considered democratic" (Volfas, 1939, p. 41);

"In 1928, the dictatorship of the coup, named after the President of the Republic, established the new formal constitutional premise. However, the politically decorative function of this act was clear" (Jaugelis, 1939, pp. 64-65);

"So our press censorship policy went in the direction of the abolition of press freedom" (Zaleskis, 1937, p. 21).

\section{FATES OF STUDENTS AND TEACHERS}

According to the data found in the Central State Archives of Lithuania about thirty graduates worked as judges, eleven as notaries, thirteen as lawyers, ten graduates became law professors. Some of them continued this activity after the Soviet occupation.

However, some fates of students reveal not only the situation in Lithuania but also in Europe: about fifty graduates of the Faculty of Law emigrated, twenty were taken to the ghettos, at least ten were evacuated, and several were imprisoned.

And it is just preliminary data because there are no data left for many graduates.

The fate of teachers is also ambiguous. However, first, it is noteworthy that the teachers had interesting biographies. Among them there were high governmental officials - member of Constituent Assembly Antanas Tamošaitis, the first chair of the board of the Bank of Lithuania Vladas Jurgutis, ad hoc judge of the Permanent Court of 
International Justice Mykolas Romeris, chair of the regional court of Kaunas Vladas Mačys, governor of the Memel Territory Karolis Žalkauskas, member of the State Council Domas Krivickas, minister of justice Petras Leonas, minister of finance, member of the Lithuanian Academy of Sciences Albinas Rimka, Prime Minister Antanas Tumenas, the chair of the Ministerial Legal Advisors Commission Antanas Ignas Veryha Darevskis, member of the Chamber of Commerce, Industry and Crafts Petras Šalčius. Some teachers were famous not only in law, but also in artistic work - Simonas Bieliackinas, who, incidentally, taught both civil and criminal law. Some of the teachers' legal works were known not only in Lithuania, but also in Russia, from which they had emigrated to Lithuania, e.g. Alexander Yashchenko, also already mentioned Simonas Bieliackinas.

However, the fates of the teachers were complicated and tragic. Some of them emigrated (Stasys Žakevičius, Vaclovas Biržiška, Vladimiras Stankevičius, Konstantinas Račkauskas, Domas Krivickas, Karolis Žalkauskas, Kazys Oželis, Feliksas Mackus, Mečislovas Mackevičius), others were deported, imprisoned (Tadas Petkevičius, Antanas Tumènas, Vladas Jurgutis). Simanas Bieliackinas was killed in Auschwitz concentration camp in 1944. Antanas Tamošaitis was arrested by the NKVD and died in prison in 1940.

\section{CONCLUSIONS}

1. The research revealed how the Faculty of Law prepared future lawyers, and the topicalities of Lithuania in the interwar period. Students wrote about various issues of civil, criminal, administrative, constitutional, labour, business, and international law. Students also assessed some current issues of that time: the principle of publicity in the criminal procedure, euthanasia, criminal liability of civil servants, responsibility for the termination of pregnancy, legal backgrounds of competition law, etc.

2. During the interwar period in Lithuania four civil law systems (civil laws of the Russian and German Empires, Suvalkija region and the Province of Kuršas) and two criminal law systems (laws of the Russian and German Empires) were in force. Therefore, students had to analyse several systems of legal regulation, including the case-law of the Chief Tribunal of the Republic of Lithuania, the Senate of the Tsar Russian, case law of the German courts.

3. Students' final theses were full of thoughts that could not be read in the daily newspapers of that time, especially about the prevailing authoritarian regime in Lithuania. It shows that the spirit of freedom at the Faculty of Law was maintained by the president of Vytautas Magnus University Mykolas Romeris.

4. Fates of students and teachers reveal not only the situation in Lithuania but also in Europe: some of them were evacuated, taken to ghettos, imprisoned, some emigrated, and some continued their activity in the occupied Lithuania.

\section{BIBLIOGRAPHY:}

Baudžiamasis kodeksas (1919). Lithuania: Laikinosios vyriausybės žinios.

Deviatnikovaitè, I. (2020a). Teisių fakulteto studentų darbai 1925-1939. I dalis (19251932). Law Review, 21(1), pp. 21-60. DOI: https://doi.org/10.7220/20294239.21.2

Deviatnikovaitè, I. (2020b). Teisių fakulteto studentų darbai 1925-1939. II dalis (19331934). Law Review, 21(1), pp. 61-105. DOI: https://doi.org/10.7220/2029-

4239.21.3 
Deviatnikovaitè, I. (2020c). Teisių fakulteto studentų darbai 1925-1939. III dalis (19351937). Law Review, 21(1), pp. 106-153. DOI: https://doi.org/10.7220/20294239.21.4

Deviatnikovaitè, I. (2020d). Teisių fakulteto studentų darbai 1925-1939. IV dalis (19371939). Law Review, 21(1), pp. 154-195. DOl: https://doi.org/10.7220/20294239.21 .5

Jaugelis, J. (1939). Normatyvine valdymo organy galia Lietuvos konstitucineje teisejje. Vytauto Didžiojo Universitetas.

Krasauskas, L. (1932). Atstovavimas igaliojimui. Vytauto Didžiojo Universitetas.

Lietuvos universiteto Teisių fakulteto regulaminas ir mokslo planas. (1923). Teisių fakulteto leidinys.

Lietuvos valstybės laikinosios Konstitucijos pamatiniai dèsniai (1918). Lithuania: Laikinosios vyriausybès žinių papildymas.

Maksimaitis, M. (2002). Teisių mokslai. In: E. Aleksandravičius (Ed.), Mokslas ir visuomené 1922-2002 (pp. 325-344). Kaunas: Vytauto Didžiojo universitetas.

Meškauskas, J. (1932). Teisinè reikšmè Tautu Sajungos Lietuvai. Vytauto Didžiojo Universitetas.

Šalkauskis, S. (1926). Bendrosios mokslinio darbo metodikos pradai. Kaunas.

Šalkauskis, S. (1933). Bendrosios mokslinio darbo metodikos pradai. Sakalo b-vè.

Volfas, J. (1939). Tiesioginis ir reprezentacinis valdymas. Vytauto Didžiojo Universitetas.

Zaleskis, L. (1937). Spaudos cenzūra nepriklausomoje Lietuvoje. Vytauto Didžiojo Universitetas. 
